\title{
Vermicompost Technology and its Application in Forest Nursery Raising
}

\author{
Malik Asif ${ }^{1}$, A.H. Mughal ${ }^{1}$, Zaffar Mehdi ${ }^{1 *}$, M.A. Malik ${ }^{1}$, Amjad Masood ${ }^{3}$, \\ Showket Sideeque ${ }^{4}$, Saima Shafi ${ }^{1}$ and Bisma Rashid ${ }^{1}$ \\ ${ }^{1}$ Division of Basic Sciences \& Humanities, FOA, Wadura, SKUAST-Kashmir, India \\ ${ }^{2} K V K / E T C$ Malangpora, Pulwama SKUAST-K, India \\ ${ }^{3}$ Division of Agronomy, FOA, Wadura, SKUAST-Kashmir, India \\ ${ }^{4}$ Division of Agri-Stat and Economics, FOA, Wadura, SKUAST-Kashmir, India \\ *Corresponding author
}

\section{A B S T R A C T}

Vermicompost is a nutrient-rich, microbiologically-active organic amendment that results from the interactions between earthworms and microorganisms during the breakdown of organic matter. It is a stabilized, finely divided peat-like material with a low $\mathrm{C}: \mathrm{N}$ ratio, high porosity and high water-holding capacity, in which most nutrients are present in forms that are readily taken up by plants. Earthworms act as mechanical blenders, and by

\begin{tabular}{|l|}
\hline Ke y w o r d s \\
$\begin{array}{l}\text { Forest, Nursery, } \\
\text { Vermicompost, } \\
\text { Technology }\end{array}$ \\
\hline Article Info \\
\hline $\begin{array}{l}\text { Accepted: } \\
\text { 10 December } 2018 \\
\text { Available Online: } \\
\text { 10 January } 2019\end{array}$ \\
\hline
\end{tabular}
fragmenting the organic matter they modify its physical and chemical status by gradually reducing the ratio of $\mathrm{C}: \mathrm{N}$ and increasing the surface area exposed to microorganisms - thus making it much more favourable for microbial activity and further decomposition. The use of compost in forestry and horticulture has occasionally been shown to be limited by the high electrical conductivity and the excessively high amount of certain ions that cause phytotoxicity, as a consequence of the chemical properties of the initial waste and /or inadequate composting procedures. These adverse effects, although possible, are less likely to occur when vermicompost is used as a potting amendment especially for raising forest nurseries. Production of high quality forest tree seedlings in nurseries is very important as far as tree nurseries and farmers are concerned for reversing the current degradation of natural forests, woodlands and scrublands. Quality seedling production is the main objective of forest nursery but the slow growth of seedlings limits the high quality seedling production. Readiness of seed to germinate for further multiplication is much warranted and there is a need to optimize a growing media for high quality seedling production in tree nurseries. Slow growing nature of seedlings is the major limiting factor for successful seedling production in tree nurseries which can be enhanced by standardizing the appropriate growing medium with the addition of quality vermicompost.

\section{Introduction}

Production of high quality forest tree seedlings in nurseries is very important as far as tree nurseries and farmers are concerned for reversing the current degradation of natural forests, wood lands and scrublands. Quality seedling production is the main objective of forest nursery but the slow growth of seedlings limits the high quality 
seedling production. Slow growing nature of seedlings is the major limiting factor for successful seedling production in tree nurseries which can be enhanced by standardizing the appropriate growing medium with the addition of quality vermicompost and which can improve physical properties like aeration, drainage and water holding capacity which are otherwise lacking. Nutrient value of the growing media can be enriched by addition of specific nutrients and pure cultures of beneficial microbes like plant growth promoting microorganisms (PGPR) capable of enhancing the availability of nutrients for plant growth.

Animal manure is a valuable resource as a soil fertilizer because it provides large amounts of macro- and micronutrients for crop growth and is a low-cost, environmentally-friendly alternative to mineral fertilizers. Processing of this waste material through controlled bio-oxidation processes, such as composting, reduces the environmental risk by transforming the material into a safer and more stable product suitable for application to soil (Lazcano et al., 2008).

In comparison with mineral fertilizers, compost produces significantly greater increases in soil organic carbon and some plant nutrients (Garcia-Gil et al., 2000, Bulluck et al., 2002). Long-term beneficial effects of composted materials are also observed in soil humic substances due to an increase in the complexity of their molecular structure, which increases the humic/fulvic acid ratio, as well as in soil absorption properties (with increased cation exchange capacity and base saturation) (Weber et al., 2007). The vermicompost expression is a word which is used for the final product (humus-like material) of composting procedure of organic waste materials by soil worms. Many organic wastes have been converted into worm manure (vermicompost) by different species of earthworms which include cow manure, horse waste, olive leaves, paper waste, sheep-goat manure, ground rice waste, tea-coffee wastes. Increase in the human population, industrialization and agricultural practices have led to an increased accumulation of wastes. Cow manure and vegetal wastes are the most widely used as bed ingredients in closed system for production vermicompost. An important component of sustainable nursery forest raising is vermicompost fertilizers, which have been used in many countries all over the world.

\section{Vermicomposting technology}

Vermicomposting technology is a novel and eco-friendly technology with no adverse effect on the immediate ecosystems. Vermicompost is a nutrient-rich, microbiologically-active organic amendment that results from the interactions between earthworms and microorganisms during the breakdown of organic matter. It is a stabilized, finely divided peat-like material with a low $\mathrm{C}: \mathrm{N}$ ratio, high porosity and high water-holding capacity, in which most nutrients are present in forms that are readily taken up by plants (Dominguez, 2004).

Earthworms are the crucial drivers of the process as they accelerate and fragment the substrate, thus drastically altering the microbial activity. Earthworms act as mechanical blenders, and by fragmenting the organic matter they modify its physical and chemical status by gradually reducing the ratio of C.N and increasing the surface area exposed to microorganisms - thus making it much more favourable for microbial activity and further decomposition (Dominguez et al., 2010). As a result of the different processes involved in the production of compost and 
vermicompost, they exhibit different physical and chemical characteristics that affect soil properties and plant growth in diverse ways. Vermicomposting generally converts organic matter to a more uniform size, which gives the final substrate a characteristic earthy appearance, whereas the material resulting from composting usually has a more heterogeneous appearance (Tognetti et al., 2005). The adverse effects, although possible, are less likely to occur when vermicompost is used as a potting amendment (Chaoui et al., 2003).

\section{Earthworms}

Earthworms are capable of transforming garbage into 'gold'. Charles Darwin described earthworms as the 'unheralded soldiers of mankind', and Aristotle called them as the 'intestine of earth', as they could digest a wide variety of organic materials (Darwin and Seward 1903). Soil volume, microflora and fauna influenced by earthworms have been termed as "drilosphere" and the soil volume includes the external structures produced by earthworms such as surface and below ground casts, burrows, diapause chambers as well as the earthworm body surface and internal gut associated structures in contact with the soil (Lavelle et al., 1989; Brown et al., 2000).

Earthworms intestine contains a wide range of microorganisms, enzymes and hormones which aid in rapid decomposition of halfdigested material transforming them into vermicompost in a short time (nearly 4-8 weeks) (Ghosh et al., 1999) compared to traditional composting process which takes the advantage of microbes alone and thereby requires a prolonged period (nearly 20 weeks) for compost production (Bernal et al., 1998).

As the organic matter passes through the gizzard of the earthworm it is grounded into a fine powder after which the digestive enzymes, microorganisms and other fermenting substances act on themfurther aiding their breakdown within the gut, and finally passes out in the form of "casts" which are later acted upon by earthworm gut associated microbes converting them into mature product, the "vermicomposts"

\section{Earthworm species suitable for vermicompost production}

The following earthworm species may be used for preparation of vermicompost

Eisenia foetida (red worm)

Eudrilus eugeniae (night crawler)

Perionyx excavates

\section{Production technology of vermicompost}

\section{Raw materials required}

Cow dung and any other biodegradable waste such as crop residues, forest leaf litter, weed biomass, vegetable wastes, slaughter house waste, bio-degradable portion of urban and rural wastes etc. may be used for the preparation of vermicompost.

\section{Methods of preparation}

The Vermicompost can be prepared in locally made pits.

The standard size of the pits should be $8 \times 3 \times$ $3 \mathrm{ft}$ ( 1 x b x d).

The available bio-wastes are to be collected and are to be heaped under sun for about 3 weeks and covered with a shade net for predecomposition process

Sprinkling of cow dung slurry to the heap may be done.

A thin layer of half decomposed cow dung (12 inches) is to be placed at the bottom.

Place the chopped weed biomass/ partially decomposed leaf litter and cow dung layer wise $(10-20 \mathrm{~cm})$ in the pits upto the depth of 3 $\mathrm{ft}$. 
The bio waste and cow dung ratio should be 60: 40 on dry wt. basis.

Release about 2-3 kg earthworms per pit.

Place wire net / shade net over the pits to protect earthworm from birds

Sprinkling of water should be done to maintain 70-80\% moisture content.

Turning of bio-waste material should be done at an interval of 15 days.

Provision of a shed over the compost is essential to prevent entry of rainwater, snow and direct sunshine.

Sprinkling of water should be stopped when $90 \%$ bio-wastes are decomposed. Maturity could be judged visually by observing the formation of granular structure of the compost at the surface of the pit.

Harvest the Vermicompost by scrapping layer wise from the top of the pit and heap under shed. This will help in separation of earthworms from the compost. Sieving may also be done to separate the earthworms and cocoons.

\section{Separation of earthworms and cocoon}

Heap the harvested vermicompost for 6-12 hours under shade for separation of the earthworm.

Sieve vermicompost for separation of baby earthworm and cocoons.

Dry vermicompost (if necessary) under shade to keep the moisture content below 20 per cent.

Separate earthworms and cocoons for reuse.

\section{Protection from enemies}

Bio-wastes free from ants /termites etc are to be used for vermicompost preparation.

The vermicompost thus prepared would normally have the nutrients of following concentrations (Table 1).

\section{Advantages of vermicompost}

Vermicompost is a rich source of vitamins, hormones, enzymes, macro and micronutrients which when applied to plants help in efficient growth (Prabakaran, 2005)

The vermiculture provides for the use of earthworms as natural bioreactors for costeffective and ecofriendly waste management (Aalok et al., 2008).

Provides excellent effect on overall plant growth, encourages new shoots/ leaves and improves the quality and self-life of the produce.

Vermicompost is free flowing, easy to handle, store and apply and does not have bad odour.

Earthworms change the soil in many beneficial ways. They increase the soil's plant available nutrient content (example: nitrates, phosphates, exchangeable calcium and soluble potassium), growth regulators and useful bacterial populations (Bhadauria and Ramakrishnan, 1996).

Improves soil structure, texture, aeration, water holding capacity and prevents soil erosion.

Vermicompost is rich in beneficial microflora such as $\mathrm{N}$ fixers, P-solubilizers, cellulose decomposing micro-flora etc.

The digestive enzymes of earthworm are responsible for the decomposition and humification of organic matter. These enzymes are active at a very narrow $\mathrm{pH}$ range and efficiently maintain the non - linear $\mathrm{pH}$ parameters (Gajalakshmi and Abbasi, 2003) Vermicompost is rich in several enzymes and growth regulators such as auxins, gibberellins etc.

Vermicompost contains earthworm cocoons and increases the population and activity of earthworm in soil.

Prevents nutrient losses and increase the use efficiency of chemical fertilizers.

Vermicompost is free from pathogens, toxic elements, weed seeds etc. Vermicompost minimizes the incidences of pests and 
diseases in crop

Availability of nutrients from vermicompost is faster due to its narrow $\mathrm{C}$ : $\mathrm{N}$ ratio

Vermicompost enhances the decomposition of organic matter in soil.

\section{Dosage}

The dosage of vermicompost depends upon the type of crop grown in the field/nursery. For fruit crops it is applied in the tree basin. It is added in the pot mixture for potted ornamental plants and for raising forest nurseries.

\section{Plant Dose/rate}

Pots/Polybags 100-200 g/pot

Fruit crops $3-5 \mathrm{~kg} / \mathrm{plant}$

Field crops $\quad 5-6 / \mathrm{ha}$

\section{Vermicomposting derived liquids}

The beauty of vermicomposting if compared with conventional composting process is that the time span for stabilizing and processing the waste is shorten, even though it does not undergo thermophilic phase of composting. In vermicomposting process, earthworms will ingest the substrate introduced into the reactor. There are few terms that can be found in describing vermicomposting derived liquids. The common ones are like

1. vermiwash, 2. vermicomposting leachate 3 . vermicompost aqueous extracts

\section{Effects of vermicompost on plant growth}

Vermicompost significantly stimulates the growth of a wide range of plant species including several ornamental hedges and horticultural crops. Positive effects of vermicompost have also been observed in forestry species such as acacia, eucalyptus and pine tree (Lazcano et al., 2010a, 2010b). Vermicompost has been found to have beneficial effects when used as a total or partial substitute for mineral fertilizer in peat-based artificial greenhouse potting media and as soil amendments in field studies. variations were observed in an experiment studying the effects of vermicompost and vermicompost extracts on the germination and early growth of six different progenies of maritime pine Lazcano et al., (2010a).

In this experiment, the speed of maturation increased, relative to the control without vermicompost, in three out of the six pine progenies, decreased in two of the progenies and was unaffected in the other. It may be expected that different hybrids or plant genotypes will respond differently to vermicompost, considering that plant genotype determines important differences in nutrient uptake capacity, nutrient use efficiency and resource allocation within the plant. Different genotypes may therefore enhance root growth or modify root exudation patterns in order to increase nutrient uptake (Cavani and Mimmo, 2007), and all of these strategies will determine the establishment of different interactions with the microbial communities at the rhizosphere level.

Vermicompost has also been found to have a wide range of indirect effects on plant growth such as the mitigation or suppression of plant diseases. Suppression of plant diseases has been extensively investigated in other organic amendments such as manure and compost. Likewise, some studies have shown that vermicompost can suppress a wide range of microbial diseases, insect pests and plant parasitic nematodes. As regards the suppression of fungal diseases. The aqueous extracts of vermicompost are capable of reducing the growth of pathogenic fungi such as Botrytis cinerea, Sclerotinia sclerotiorum, Corticium rolfsii, Rhizoctonia solani and Fusarium oxysporum.

\section{Future thrust}

The technology of utilizing forest and agricultural waste/biomass for production of Vermicompost needs to be popularized among 
the foresters and ecologists. For this purpose, to the line departments of forestry and extensive trainings are required to be provided horticulture.

Table.1 Nutritional composition of vermicompost

\begin{tabular}{|l|l|}
\hline Nutrients & Percentage(\%) \\
\hline Nitrogen & 1.9 \\
\hline Phosphorus & 1.18 \\
\hline Potassium & 1.88 \\
\hline Calcium & $0.5-1.0$ \\
\hline Magnesium & $0.2-0.3$ \\
\hline Sulphur & $0.4-0.5$ \\
\hline Iron & $0.8-1.5$ \\
\hline Copper $(\mathrm{ppm})$ & 18 \\
\hline Zinc $(\mathrm{ppm})$ & 100 \\
\hline
\end{tabular}

Establishment of demonstration units $(5-6$ in no.) in every range of the division will definitely help in popularizing the technology among the different wings of the forest department.

In conclusion the concept of vermicompost technology in the forest department has not received due attention during the past as compared to agriculture sector due to many reasons. The success of composting depends upon the fecundit of the earthworm. It has the efficiency to consume all types of organic rich waste material including leaf litter, vegetable wastes, industrial, dairy farm wastes, garden waste, sugar mill residues, slaughter house waste, hatcher waste and municipal wastes. The protocol for production of vermicompost from different sources of raw materials has been developed recently by Division of Basic Science \& Humanities, Faculty of Agriculture, SKUAST-Kashmir. Three exotic earthworm species have been identified for efficient vermicomposting but out of these three species, Eiseniafoetida has an outstanding performance under temperate Kashmir Himalayas. Forest department of $\mathrm{J} \& \mathrm{~K}$ has a tremendous scope to adopt the technology for raising quality nursery stock and rearing of vermiculture could also prove as the additional source of income to the department.

\section{References}

Aalok, A., Tripathi A.K and Soni.P. 2008. Vermicomposting: A better solution for organic solid waste management. Journal of Human Ecology. 24, 59- 64

Bhadauria, T., and Ramakrishnan, P.S. 1996.Population Dynamics of earthworms and their activity in forest ecosystems of North- East. Journal of Tropical Ecology.7: 305- 318.

Bernal MP, Faredes C, Sanchez-Monedero MA, Cegarra J.1998. Maturity and stability parameters of composts prepared with a, wide range of organic wastes. Bioresour Technol, 63:91-99

Brown G. G, Barois I, Lavelle P. 2000. Regulation of soil organic matter dynamics and microbial activity in the drilosphere and the role of interactions with other edaphic functional domains. Eur J Soil Biol, 36:177-198

Bulluck, L.R., Brosius, M., Evanylo, G.K. and Ristaino, J.B. 2002. Organic and synthetic fertility amendments influence soil microbial, physical and chemical properties on organic and conventional farms. Applied Soil Ecology, 19, 147-160.

Cavani, N. and Mimmo, T. 2007. Rhizodeposition of Zea mays L. as affected by heterosis. Archives of Agronomy and Soil Science, 
$53,593-604$.

Chaoui, H.I., Zibilske, L.M. andOhno, T. 2003. Effects of earthworm casts and compost on soil microbial activity and plant nutrient availability. Soil Biology and Biochemistry, 35, 295-302.

Darwin F, Seward AC. 1903. More letters of Charles Darwin. In: John M (ed) A record of his work in series of hitherto unpublished letters, vol. 2., London, p 508.

Domínguez, J. 2004. State of the art and new perspectives on vermicomposting research. In: C.A. Edwards (Ed.). Earthworm Ecology (2nd edition). CRC Press LLC. Pp. 401-424.

Domínguez, J., Aira, M. and Gómez Brandón, M. 2010. Vermicomposting: earthworms enhance the work of microbes. In: $\mathrm{H}$. Insam, I. Franke-Whittle and M. Goberna, (Eds.), Microbes at Work: From Wastes to Resources (pp. 93-114).

Gajalakshmi, S., and Abbasi, S.A.2003. High rate vermicomposting systems for recycling paper waste. Indian Journal of Biotechnology. 2: 613- 615.

Ghosh M, Chattopadhyay GN, Baral K. 1999. Transformation of phosphorus during vermicomposting. Bioresour Technol 69:149-154

Garcia-Gil, J.C., Plaza, C., Soler-Rovira, P. and Polo, A. 2000. Long-term effects of municipal solid waste compost application on soil enzyme activities and microbial biomass. Soil Biology and Biochemistry, 32 (13), 1907-1913.

Lazcano, C., Sampedro, L., Zas, R. and
Domínguez, J. 2010a. Vermicompost enhances germination of the maritime pine (Pinus pinaster Ait.). New Forest. 39, 387-400.

Lazcano, C., Sampedro, L., Zas, R. and Domínguez, J., 2010b. Assessment of plant growth promotion by vermicompost in different progenies of maritime pine (Pinus pinaster Ait.). Compost Science and Utilization; 18, 111-118.

Lavelle E, Barois I, Martin A, Zaidi Z, Schaefer R. 1989. Management of earthworm populations in agro-ecosystems: A possible way to maintain soil quality? In: Clarholm M, Bergstrom L (eds) Ecology of Arable Land: Perspectives and Challenges. Kluwer Academic Publishers, London, pp 109-122.

Prabakaran, J., 2005. Biomass resources in vermicomposting, In: proceedings of the State Level Symposium on Vermicomposting Technology for Rural Development, Madurai, Tamil Nadu, India. 27- 40.

Tognetti, C., Laos F., Mazzarino, M.J. and Hernández, M.T. 2005. Composting vs. vermicomposting: A comparison of end product quality. Compost Science and Utilization, 13, 6-13.

Weber, J., Karczewska, A., Drozd, J., Licznar, M., Licznar, S., Jamroz, E. and Kocowicz, A. 2007. Agricultural and ecological aspects of a sandy soil as affected by the application of municipal solid waste composts. Soil Biology and Biochemistry, 39, 1294-1302.

\section{How to cite this article:}

Malik Asif, A.H. Mughal, Zaffar Mehdi, M.A. Malik, Amjad Masood, Showket Sideeque, Saima Shafi and Bisma Rashid. 2019. Vermicompost Technology and its Application in Forest Nursery Raising. Int.J.Curr.Microbiol.App.Sci. 8(01): 1290-1296. doi: https://doi.org/10.20546/ijcmas.2019.801.137 